\title{
Immunochemical and ultrastructural study of multiple myeloma with a heavy chain protein in the serum
}

\begin{abstract}
CARLO BARTOLONI,* GIOVANNA FLAMINI, $\dagger$ NICOLA GENTILONI,* MATTEO A RUSSO, $\ddagger$ CARLO BARONE,* GINO GAMBASSI,* AND TULLIO TERRANOVA $\dagger$

From the *Istituto di Patologia Speciale Medica, Università Cattolica Sacro Cuore, Rome, †Istituto di Patologia Generale, Università Cattolica Sacro Cuore, Rome, and $\ddagger$ Istituto di Patologia Generale, Università degli Studi, Rome, Italy
\end{abstract}

SUMMARY A patient with multiple myeloma had antigenically related monoclonal Fc-gamma fragments and complete IgG-kappa molecules in the serum. The urine contained only Fc-gamma fragments in the absence of Bence-Jones protein. The two distinct M-components in the serum showed electrophoretic identity but could be separated by chromatography. The simultaneous presence of complete monoclonal IgG molecules and Fc-gamma fragments, though difficult to detect, could be a frequent occurrence in multiple myeloma, and it could be defined as 'double paraproteinaemia'. A detailed ultrastructural study was performed in this case and showed fibril bundles being released from the malignant plasma cells; such fibrils could be the supramolecular organisation of the neosynthesised heavy chain fragments.

The association of a heavy-chain disease protein with a complete immunoglobulin in a monoclonal gammopathy has been described in less than 10 cases from 1968 to the present. ${ }^{1-7}$ It was observed in patients who, despite a dissimilar clinical picture, suffered mainly from a lymphoma-like disease. The clinical condition was constantly characterised by hepatomegaly and/or splenomegaly, an increased incidence of respiratory tract bacterial infections, and a complete absence of clinical and radiological lesions in the bones.

We present a case showing the clinical features of multiple myeloma (osteoporosis, bone marow plasma cell infiltration, frequent respiratory tract bacterial infections), which had two monoclonal proteins in the serum. The first protein was a complete IgG-kappa M-component, and the second was composed of Fc-gamma dimers, which were also present in very low quantities in the urine. Despite the single narrow band on cellulose acetate electrophoresis, the second M-component was suggested by the presence of monoclonal Fc-gamma fragments in the urine concentrated up to 300 -fold, proteinuria being less than $150 \mathrm{mg} / 24$ hours.

Received for publication 25 February 1980

\section{Material and methods}

METHODS FOR PROTEIN STUDIES

Zone electrophoresis was performed on cellulose acetate strips with a Saitron 5003 apparatus and a Celloscan densitometer; quantitative determination of immunoglobulins was performed by radial immunodiffusion (Behring Partigen plates) according to Mancini ${ }^{8}$; immunoelectrophoresis with the Scheidegger ${ }^{9}$ micromethod against normal human serum and anti-human immunoglobulin (or Ig fragment) monospecific sera: anti-normal human (anti-NHS), anti-gamma chain, anti-alpha chain, anti-mu chain, anti-kappa and anti-lambda light chain, anti-IgG/Fab, anti-IgG/Fc, antiIgG/Fd serum (from Behring Institute, Marburg Lahn, West Germany).

The serum gammaglobulin fraction was obtained by ammonium sulphate precipitation according to Stanworth. ${ }^{10}$

Serum gel-chromatography ${ }^{11}$ was performed on a $2.5 \times 110 \mathrm{~cm}$ Sephadex G-200 column; the pooled G-200 eluted fractions were rechromatographed on a $1.7 \times 95 \mathrm{~cm}$ Sephadex G-100 column; in both cases we used $0 \cdot 1 \mathrm{~m}$ phosphate buffer, $\mathrm{pH} 7 \cdot 6$. Urine gel-chromatography was performed on a $1.7 \times 95 \mathrm{~cm}$ 
G-100 column; the elution buffer was $0 \cdot 1 \mathrm{M}$ acetate, pH 5.4. The fractions were read by an ISCO-UA5 continuous-flow spectrophotometer (lambda $=280$ $\mathrm{nm}$ UV) and collected by an LKB apparatus.

For SDS-polyacrylamide gel electrophoresis, ${ }^{12}$ we used bovine serum albumin (BSA) (68 $000 \mathrm{MW}$ ) and carbonic anhydrase (45000 MW) as markers; molecular weight (MW) was obtained on a logarithmic scale plotting RF (run length/total gel length) against MW values.

For the subclass characterisation of the isolated immunoglobulin and fragments, double diffusion according to Ouchterlony ${ }^{13}$ was performed in $2 \%$ agar gel in saline $+2 \%$ PEG 4000 with rabbit antihuman $\mathrm{IgG}_{1}, \mathrm{IgG}_{2}, \mathrm{IgG}_{3}, \mathrm{IgG}_{4}$ monospecific sera (from the Central Laboratory of the Netherlands Red Cross Blood Transfusion Service, Amsterdam, The Netherlands). Total protein values were obtained by Lowry's ${ }^{14}$ method.

\section{METHODS FOR CELLULAR STUDIES}

\section{Electron microscopy}

For electron microscopy, buffy coat cells, prepared according to Russo, ${ }^{15}$ and sternal bone marrow aspirate were fixed ( 2 hours) in $2 \%$ glutaraldehyde in $0.1 \mathrm{M}$ phosphate buffer, $\mathrm{pH} 7 \cdot 4$, then rinsed with the same buffer ( 2 hours), and post-fixed ( 2 hours) in $1.33 \%$ osmium tetroxide solution in the same buffer. After rapid dehydration with increasing ethanol concentrations, the specimens were embedded in an Epon-812 mixture. Ultrathin sections, prepared with a diamond knife and stained with uranyl acetate (20-40 seconds) and lead hydroxide (6 minutes), were observed with a Philips-300 electron microscope.

\section{Results}

\section{CASE REPORT}

An 82-year-old woman was admitted to Agostino Gemelli Hospital of the Catholic University, Rome, in January 1977 complaining of fatigue, back pain, loss of weight, and recent bronchopneumonia for which she had received antibiotic therapy. In the same year she had been referred to two other hospitals with similar respiratory tract infections.

\section{Physical examination}

Physical examination revealed a still evolving bronchopneumonia, spontaneous pain in the dorsolumbar region, and acute pain on percusion of the sternum; in addition, we found hepatomegaly without splenomegaly in the absence of lymphadenopathy and palatal oedema.

\section{Laboratory investigations}

The routine laboratory test results were as follows: a total body skeletal $x$-ray showed a diffuse and severe osteoporosis without osteolysis; a liver biopsy showed a well-preserved structure without infiltration and/or sclerosis. The bone marrow aspirate (sternum) presented atypical, immature, polynucleated, and bizarre plasma cells (approximately $40 \%$ ), whereas the other cells maintained a normal morphology but were slightly decreased in number. Other haematological findings were: ESR $54 \mathrm{~mm} / \mathrm{h}$, haemoglobin $8.6 \mathrm{~g} / \mathrm{dl}$; red cell count $3.4 \times 10^{12} / 1$; white cell count $7.4 \times 10^{9} / 1$; platelet count $700 \times 10^{9} / 1$; total serum proteins $80 \mathrm{~g} / \mathrm{l}$; alkaline phosphatase $86 \mathrm{IU}$; differential white cell count in the normal range.

\section{Immunological data}

Serum electrophoresis on cellulose acetate showed hypoalbuminaemia $(34.9 \mathrm{~g} / \mathrm{l})$ and a quite homogeneous and sharp migration band in the gammaglobulin region, which was $32.2 \%$ of the total proteins (Fig. 1). Quantitative determination of immunoglobulins showed: IgG $44.5 \mathrm{~g} / 1(4450 \mathrm{mg} /$ $100 \mathrm{ml}), \quad$ IgA $0.9 \mathrm{~g} / \mathrm{l}(90 \mathrm{mg} / 100 \mathrm{ml})$, and IgM $11.0 \mathrm{~g} / 1(110 \mathrm{mg} / 100 \mathrm{ml})$.

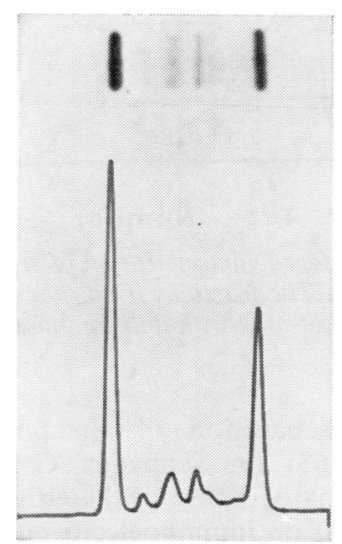

Fig. 1 Serum electrophoresis showing a homogeneous migration band in the gammaglobulin region.

Serum immunoelectrophoresis showed an anomalous precipitation arc with rabbit anti-human gamma heavy chain serum and a very faint precipitation arc with anti-kappa light chain serum.

Urine immunoelectrophoresis showed no demonstrable precipitation arcs against anti-NHS at a concentration of 100 -fold, usually sufficient to demonstrate Bence-Jones proteinuria in most cases of multiple myeloma. When the urine was concentrated up to 300 times, immunoelectrophoresis 
revealed an anomalous precipitation arc against only anti-gamma heavy chain (or Fc-gamma) serum.

\section{Protein studies}

Serum gel-chromatography on Sephadex G-200 was performed (Fig. 2) and the isolated fractions (tubes 48 to 65) developed an immunoelectrophoretic precipitation arc abnormally shaped in the cathodal tract with anti-gamma heavy chain and anti-Fc gamma monospecific sera, while no precipitation arcs were found with anti-light chain (kappa or lambda) sera.

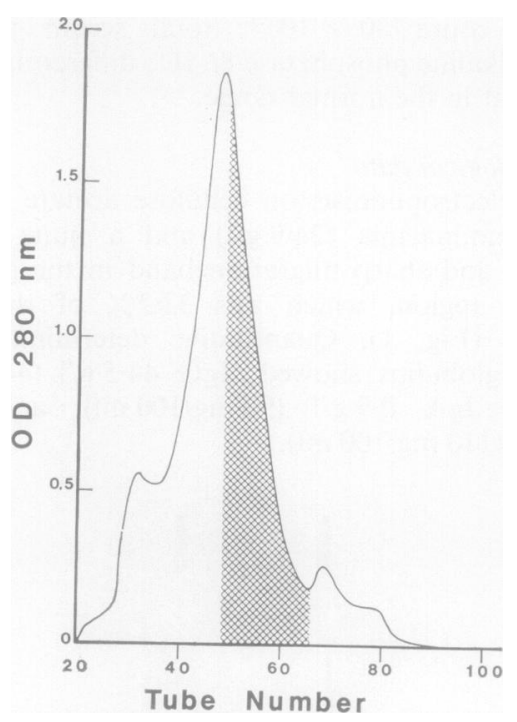

Fig. 2 Chromatographic separation of serum on Sephadex $G-200$. The fractions from tubes 48 to 65 (shaded area) react only with anti-Fc gamma, and anti-gamma sera.

A further separation of the pooled fractions (tubes 48 to 65 ) on Sephadex G-100 gave two different chromatographic peaks (Fig. 3). The first (tubes 45 to 68) on immunoelectrophoretic analysis showed an irregular precipitation arc with anti-Fab gamma (Fig. 4a), anti-Fc gamma (Fig. 4b), and anti-kappa (Fig. 4c) sera, respectively. This fraction contained a complete monoclonal IgG-kappa protein, further characterised as belonging to the $G 1$ subclass by means of double diffusion performed with monospecific anti-IgG subclass sera. The second peak (tubes 70 to 88 ) showed an abnormal precipitation arc only with anti-gamma heavy chain and anti-Fc gamma sera, and not with anti-Fab gamma, anti-kappa, or anti-lambda sera (Fig. 5).

A similar detailed study was performed on the urine. The total 24-hour urine protein was about

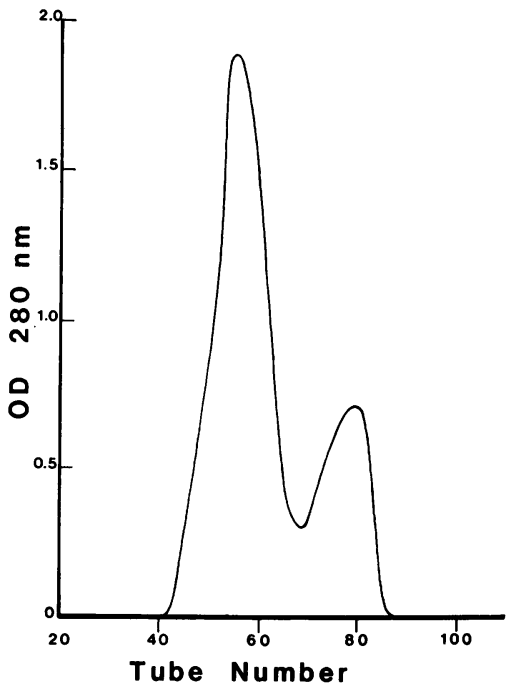

Fig. 3 Chromatographic separation of pooled fractions (tubes 38 to 65) on Sephadex G-100. No reaction is obtained with monospecific anti-light chain (kappa or lambda) sera from the fractions eluted with the second peak.

$100 \mathrm{mg} / 100 \mathrm{ml}(\mathrm{Ig} / \mathrm{l})$, but, also after routine concentration, it was still too low for electrophoretic studies; therefore, it was necessary to concentrate the urine sample up to 350 -fold to find either a faint anodal band related to albumin or a monoclonal cathodal band. The latter showed, on immunoelectrophoresis, an abnormal precipitation arc with anti-Fc gamma (Fig. 6a) and anti-gamma heavy chain (Fig. 6b) sera, but no precipitation arcs with antiFab gamma, anti-kappa, or anti-lambda sera.

The fragments were further characterised as belonging to the $\mathrm{G} 1$ subclass, as previously described. SDS-polyacrylamide gel electrophoresis on serum and concentrated urine showed that the unique thick band of urine migrated in close relation with an analogous thick band present in the serum; their approximate molecular weight was estimated to be about 50000 (Fig. 7). After mercaptoethanol reduction $^{16}$ of this gamma chain related protein, the resulting $24000 \mathrm{MW}$ fragments were considered as monomers.

\section{Light microscopy studies}

On light microscopy of marrow smears, $40 \%$ plasma cells were counted. Most of them appear irregular in shape, frequently polynucleated (2-6 nuclei), and containing one or more nucleoli.

\section{Electron microscopy studies}

Under the electron microscope, different morphologi- 


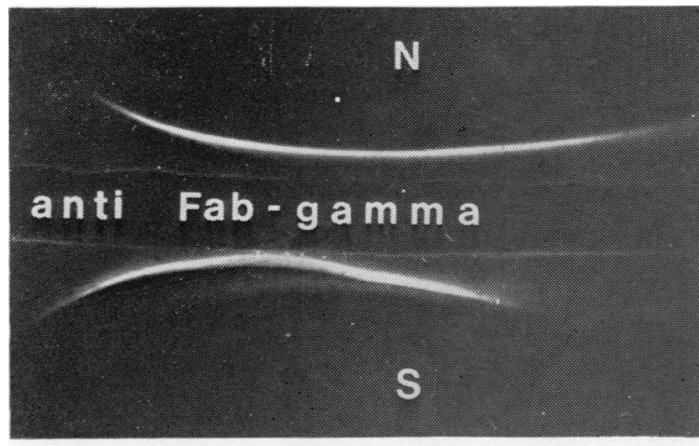

a

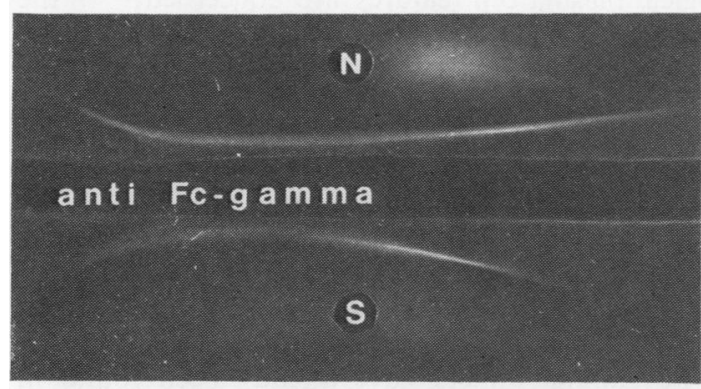

b

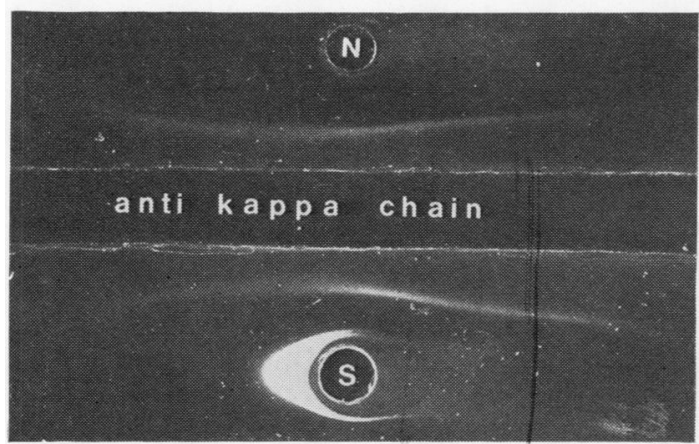

c

Fig. 4 Immunoelectrophoresis of serum fractions eluted with the first peak on Sephadex G-100 (tubes 45 to 68). An anomalous precipitation arc is obtained against antiFab gamma (a), anti-Fc gamma (b), and anti-kappa (c) sera.

cal populations of plasma cells could be detected. The most frequent type is shown in Fig. 8, and its features are similar to those described in other myelomatous or heavy chain disease plasma cells. In particular, the rough endoplasmic reticulum (RER) is abundant, it frequently presents annulate lamellae, and its cisternae are full of a homogeneous, dense material (Fig. 9). The Golgi apparatus is also quite

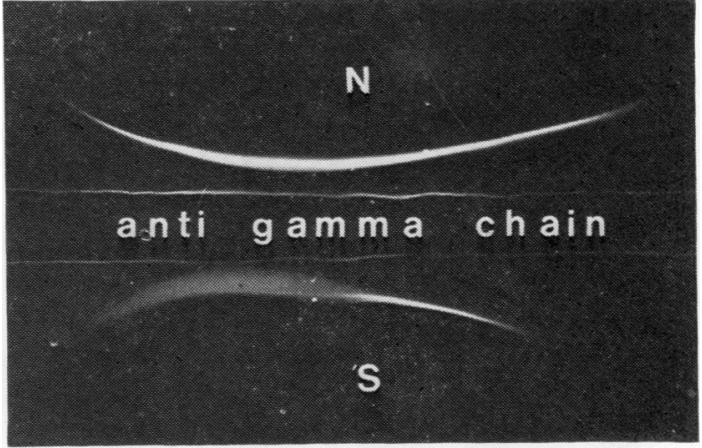

Fig. 5 Immunoelectrophoresis of serum fractions eluted with the second peak on Sephadex G-100 (tubes 70 to 88). An abnormal precipitation arc is obtained only with anti-gamma heavy chain and anti-Fc gamma sera.

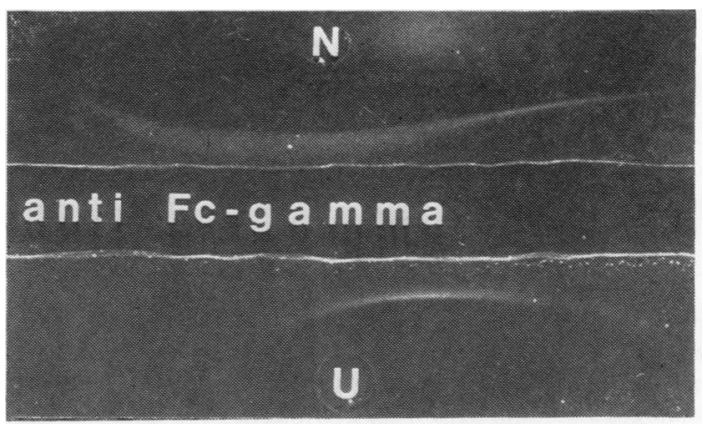

a

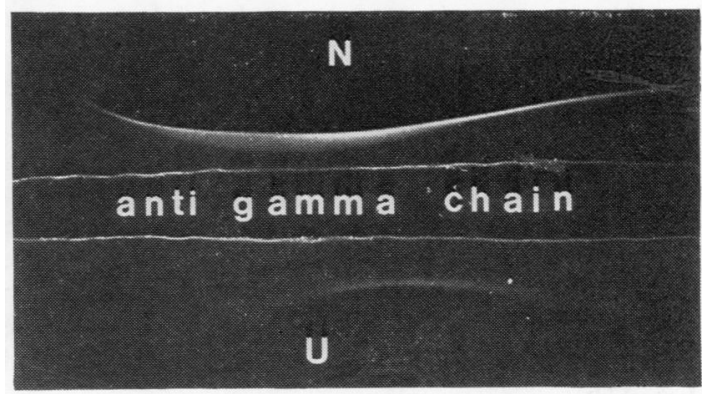

b

Fig. 6 Immunoelectrophoresis of urine. An abnormal precipitation arc is obtained only with anti-Fc gamma (a) and anti-gamma (b) sera.

abundant (Fig. 9); in its maturing (concave) face different sized vesicles are seen, containing a very electron-dense material; some of the largest are deformed by their crystalline content, which is well recognized only at times, and at others can be deduced 


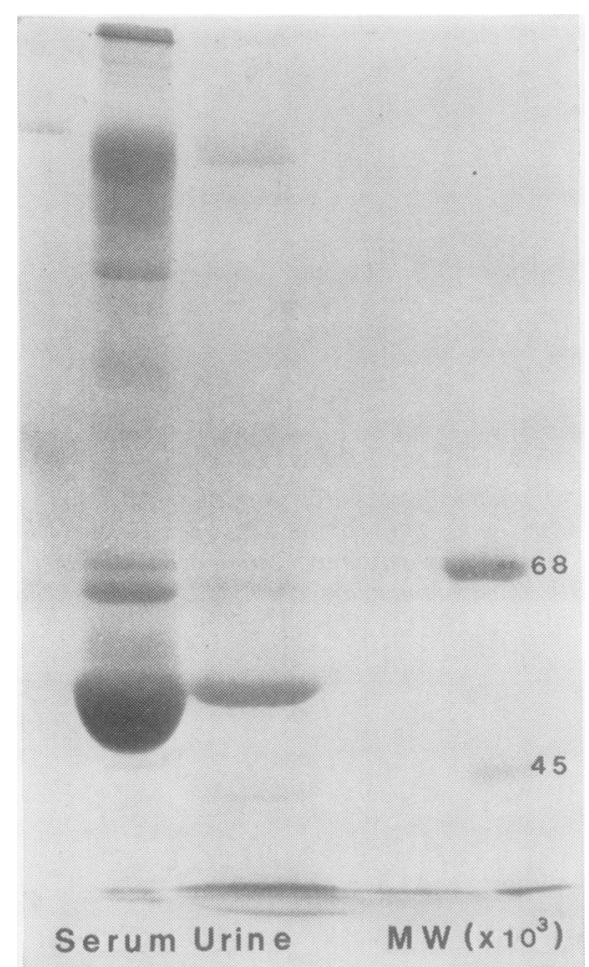

Fig. 7 SDS-polyacrylamide gel electrophoresis of serum and urine. The unique thick, homogeneous, and narrow band of urine migrates in close relation with an analogous band of serum (approximate $M W=50000$ ).

from the hexagonal or pentagonal vesicle perimeter (Fig. 10a, b, c).

In close relation to the Golgi apparatus and to the RER, numerous fibril bundles (9-10 nm diameter) are seen (Fig. 9). Despite the difficulty of identifying their origin, they seem to originate from Golgi apparatus dictosomes cisternae (Fig. 9) or from the open RER cisternae (Fig. 11a). In some cases we noted that part of the cytoplasm containing such bundles seems to come off the plasma cell to release its fibrillar and cytosolic content in the blood (Fig. 11b).

\section{Treatment and course}

The patient survived for one year, complaining during that time of increasing bone pain. Despite the administration of cyclophosphamide she died in August 1978. A necropsy confirmed the bone marrow aspirate and radiological findings.

\section{Discussion}

Two different monoclonal components were found in the serum of a patient suffering from clinical multiple myeloma. The first M-component has been identified as an IgG1-kappa protein and the second as an Fc gamma 1 fragment (comparable to a gamma heavy chain protein). Despite the presence of a heavy chain protein in the serum, the clinical pattern was different from that of classical Franklin's disease.

Many of the signs that give a lymphoma-like pattern to Franklin's disease were absent, such as palatal oedema, erythema, as well as lymph node, liver, and spleen involvement. ${ }^{17} 18$ On the other hand, this case is much more like a multiple myelo$\mathrm{ma}$, as far as the severe osteoporosis and morphological plasma cell features are concerned;19-21 the increased respiratory tract infection, however, is a less specific sign present in both diseases, probably due to the relative humoral immunity deficiency.

On zone electrophoresis, as only one M-component was detectable, the complete IgG-kappa monoclonal protein and the gamma chain fragments could not be shown. The presence of the latter, successively isolated by means of gel-chromatography in the serum, was merely suggested by the finding of Fc gamma fragments in the urine.

Fc gamma dimers have already been found in extremely low quantities by other authors ${ }^{22}$ in the serum of normal people, whereas in our patient they represented about one-third of the total myelomatous protein, as shown by chromatographic separation on Sephadex G-100.

Ultrastructural observations enabled us to correlate the immunochemical results with the abnormal plasma cell features. Electron micrographs, in addition to the moderately electron-dense material located in the RER cisternae, show two main storage sites of organised material in pathological plasma cells. The first appears as granules of various sizes originating from the Golgi apparatus and consisting of dense material often in a crystalline form, similar to Russel's bodies found in classic myeloma plasma cells. The second is represented by numerous $10 \mathrm{~nm}$ fibril bundles. Such fibrils have been described frequently in myelomatous plasma cells, ${ }^{19-21}$ but their meaning has not yet been clarified.

Our ultrastructural findings and previously reported data on supramolecular organisation are consistent with those experimental models, ${ }^{23-25}$ which showed that intracytosolic microfilaments and microfibrils may originate from monomeric or dimeric globular proteins (45000-60 000 MW) and polymerise as filaments. Subsequently, two such filaments give place to a supramolecular arrangement (eg, microfilament or microfibril). An analogous process could have taken place in our patient's 


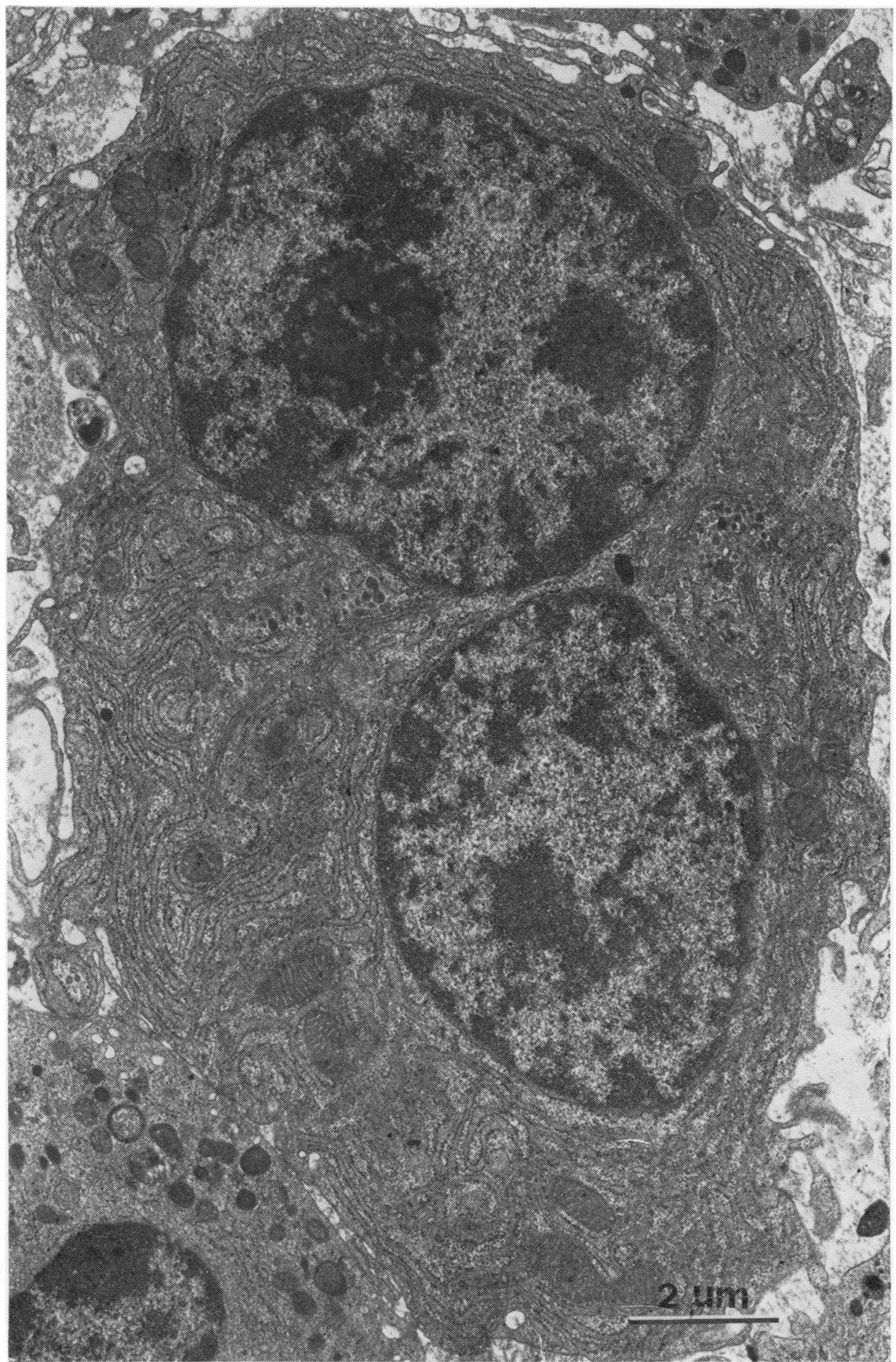

Fig. 8 Electron micrograph of a binucleated plasma cell ( $\times 12500)$. 


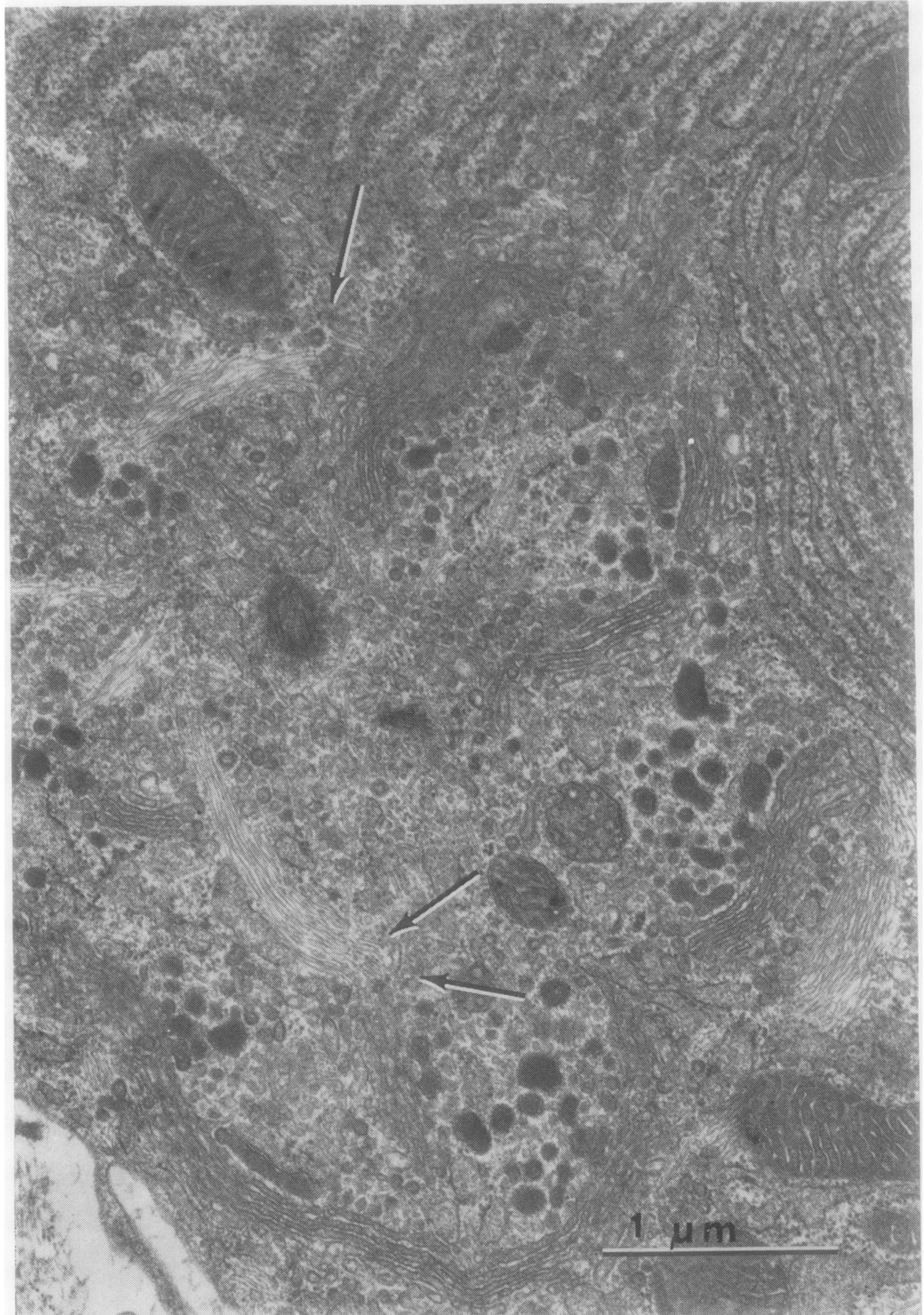

Fig. 9 Detail of a Golgi zone presenting parallel membrane arrangement, numerous dense vesicles of various size, and fibril bundles, which seem to originate from the Golgi apparatus vesicles (arrow) $(\times 34000)$. 


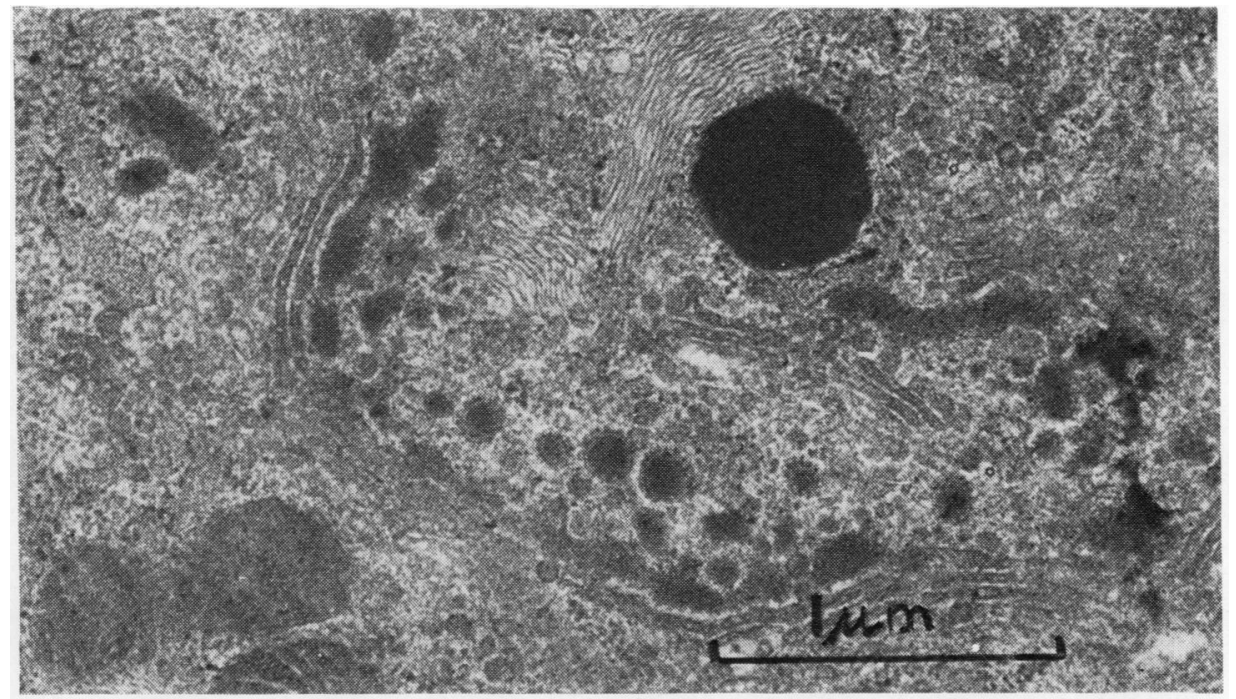

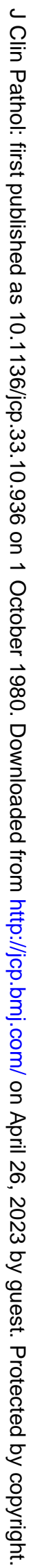

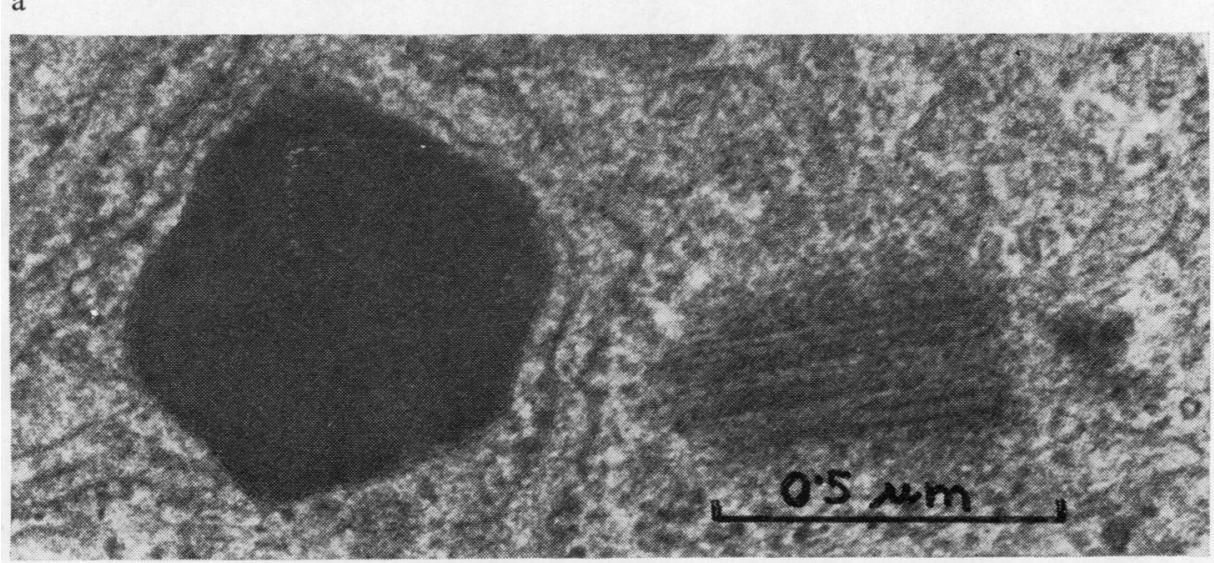

b

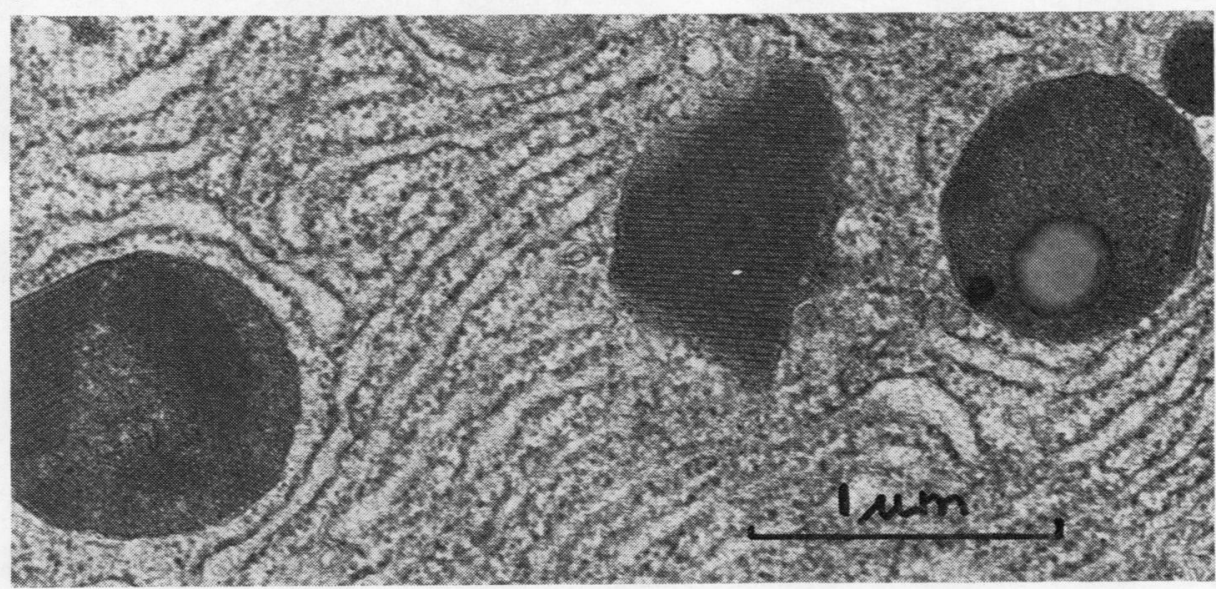

$\mathrm{c}$

Fig. 10 Various aspects of Russel's bodies.

(a) Golgi apparatus with numerous dense vesicles, fibril bundles, and one large paracrystalline granule $(\times 36000)$

(b) Detail of a polygonal granule. The crystalline array is probably lost with the fixation and embedding procedures $(\times 72000)$.

(c) In other plasma cells (nearer to the specimen surface) the paracrystalline array of the granules is well preserved $(\times 32000)$. 


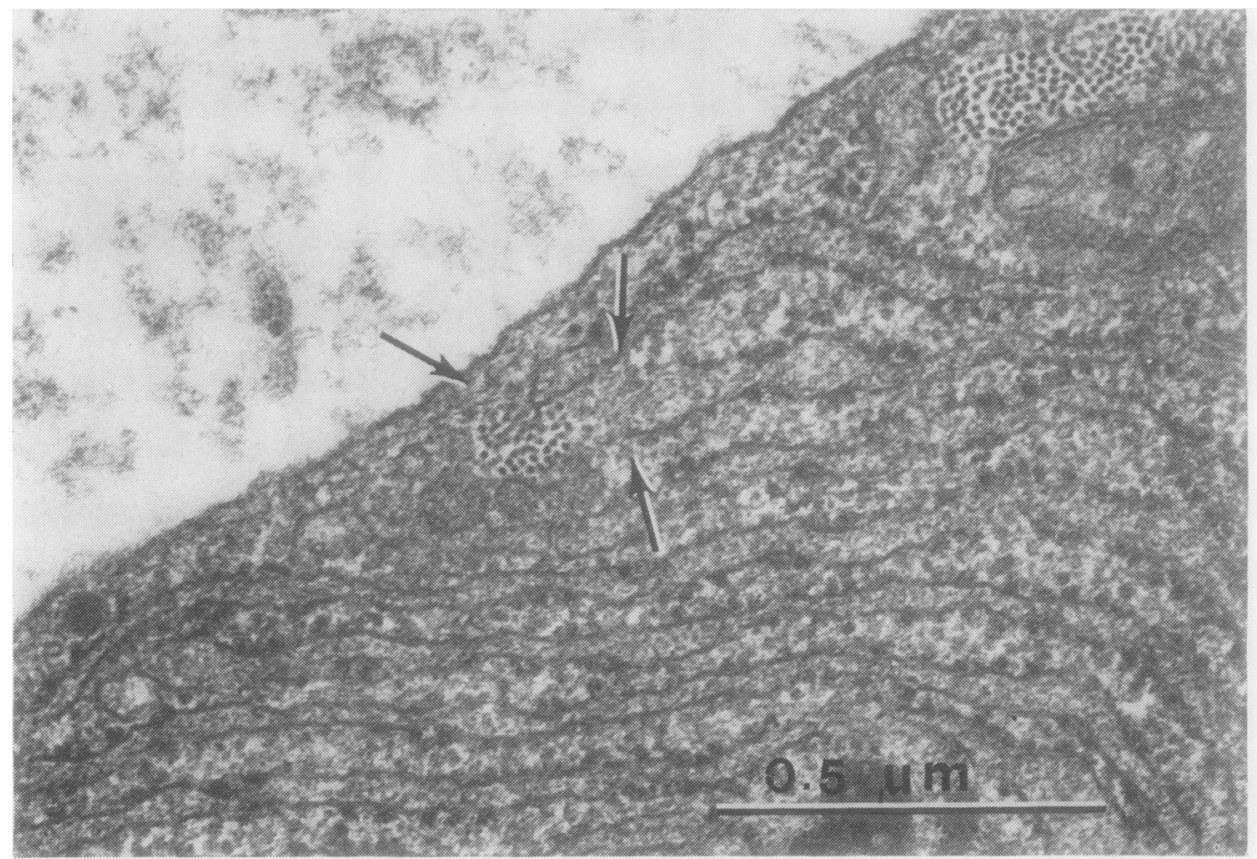

a

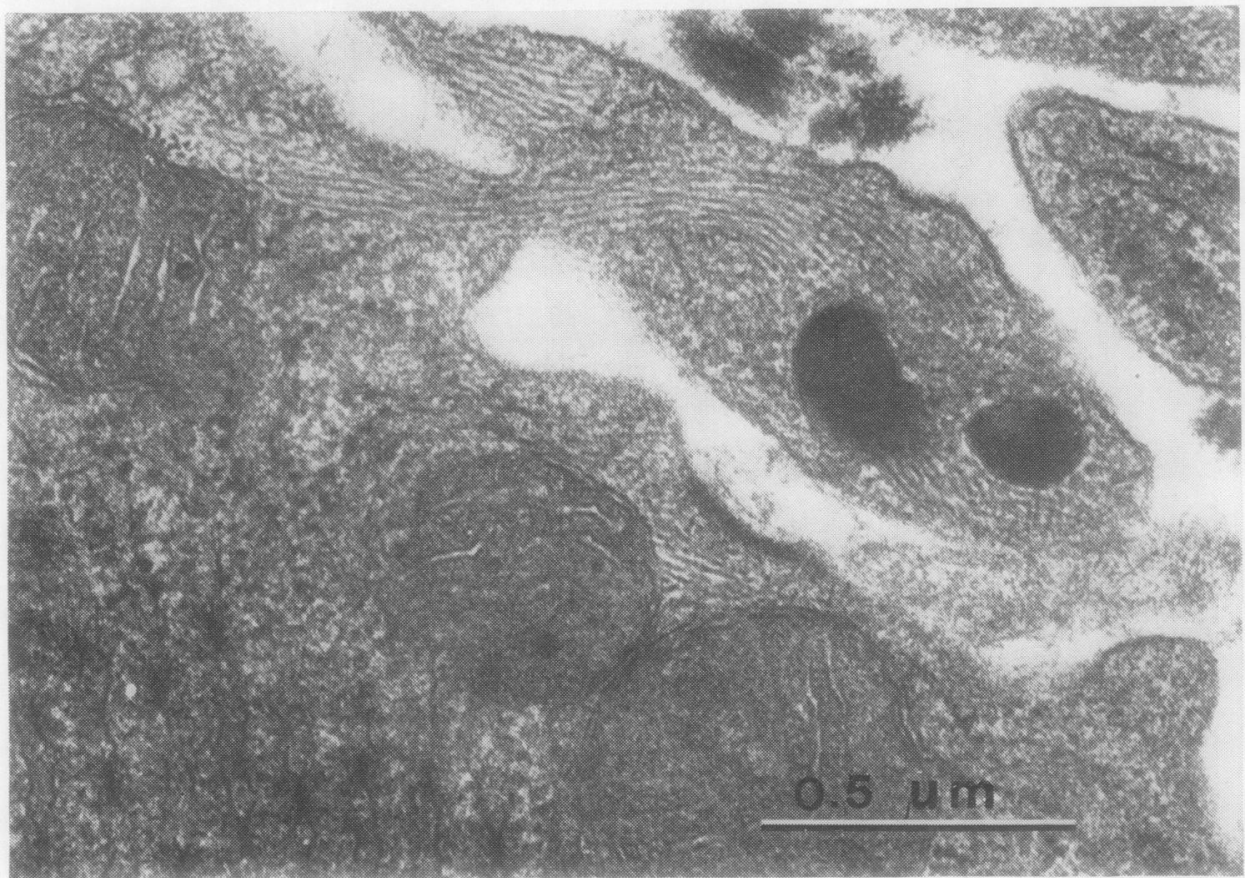

b

Fig. 11 Morphodynamic appearance of the fibrils.

(a) Microfibrils and their probable subunits near an open RER cisterna $(\times 81000)$.

(b) Clasmatosis with abundant microfibrils $(\times 65000)$. 
plasma cells if we assume that a globular dimer (Fc gamma fragment) might be produced by the endoplasmic reticulum and transferred to the Golgi apparatus.

Figures 9, 11a, and 11b show a close spatial relation between these organules and the fibrils. For such molecules this arrangement is probably consistent with the thermodynamic minimum-energy state conformation and with the intracytosolic ionic content. ${ }^{2426}$ For this reason it is not likely that such fibrils are composed of the complete monoclonal immunoglobulin, which is normally found in Russel's bodies, as described in classical multiple myeloma.

Finally, at the periphery of the plasma cell, the fibril bundles enveloped in a part of the cytoplasm, seemed to be released from the cell. The dimers found in the serum and urine could represent the depolymerisation product of the released fibrils, due to the different ionic strength and energy charge of the haematic environment, in comparison with the cytosolic milieu. These sequential phases support the hypothesis of a 'de novo' synthesis of such fragments.

Buxbaum and Alexander ${ }^{27}$ obtained from a plasma cell culture heavy chain fragments, presenting a molecular weight similar to that of our fragment, with no evidence of a larger molecule. According to Adlersberg, ${ }^{1}$ such fragments might be a synthetic product, being the mutation result of the malignant clone already producing the complete protein. However, we cannot exclude the possibility that serum Fc gamma fragments might result from the proteolytic cleavage of the complete immunoglobulin by physiological plasma endopeptidases. ${ }^{3}$

\section{References}

1 Adlersberg JB, Grann V, Zucker-Franklin D, Frangione B, Franklin EC. An unusual case of plasma cell neoplasm with an IgG 3-lambda myeloma and a gamma 3 heavy chain disease protein. Blood 1978;51:85-91.

${ }^{2}$ Fine SM, Zakin MM, Faure A, Boffa GA. Myeloma avec paraproteine sérique et élimination urinaire d'infragment de $\mathrm{G}$ depourva de chaines légères. Revue Française d'Etudes Cliniques et Biologiques 1968;13:175-8.

${ }^{3}$ Isobe T, Osserman EF. Plasma cell dyscrasia associated with the production of incompleted IgG molecules, gamma heavy chains, and free lambda chains containing carbohydrate: description of the first case. Blood 1974; 43:505-26.

4 Josephson AS, Nicastri A, Price A, Biro L. H $\mu$ chain fragment and monoclonal IgG in a lymphoproliferative disorder. Am J Med 1975;54:127-35.

${ }^{5}$ Keller H, Spengler GA, Skvaril F. Zur Frage der heavy chain disease. Ein Fall von IgG-heavy-chain-fragment und IgM-typk-paraproteinaemia mit plasmazellen Leukaemie. Schweiz Med Wochenschr 1970;100:1012-22.

${ }^{6}$ Wang A, Fudenberg HH, Goldrosen MH, Greedman MH. Chemical studies of heavy chains of two IgG1 lambda myeloma proteins from a single patient. Immunol Chem 1972;9:473-9.
${ }^{7}$ Feremans W, Caudron M, Bieva C. A case of $\gamma 3$ heavy chain disease with vacuolated plasma cells: a clinical immunological, and ultrastructural study. J Clin Pathol $1979 ; 32 ; 334-43$.

${ }^{8}$ Mancini G, Carbonara AO, Heremans JF. Immunochemical quantitation of antigens by single radial immunodiffusion. Immunochemistry 1965;2:235-54.

${ }^{9}$ Scheidegger JJ. Une micromethode de l'electrophorese (A micromethod for immunoelectrophoresis). Int Arch Allergy 1955;7:103-10.

${ }^{10}$ Stanworth DR. A rapid method of preparing pure serum gammaglobulin. Nature 1960;188:156-7.

11 Ackers GK. Molecular exclusion and restricted diffusion processes in molecular-sieve chromatography. Biochemistry 1964;3:723-30.

12 Shapiro AL, Maizel JV. Molecular weight estimation of polypeptides by SDS-polyacrylamide gel electrophoresis; further data concerning resolving power and general considerations. Anal Biochem 1969;29:505-14.

${ }^{13}$ Ouchterloney O. Antigens-antibody reactions in gels. IV. Types of reaction in coordinated systems of diffusion. Acta Pathol Microbiol Scand 1953;32:231-40.

${ }^{14}$ Lowry OH, Rosebrough NJ, Farr AL, Randall RJ. Protein measurement with the folin phenol reagent. J Biol Chem $1951 ; 193: 265-75$.

${ }^{15}$ Russo MA. A new tube for preparing the buffy coat for electron microscopy. Stain Technol 1977;52:178-81.

${ }^{16}$ Fleischman JB, Pain R, Porter RR. Reduction of gamma globulins. Arch Biochem Biophys 1962; Suppl. 1:174.

${ }^{17}$ Franklin EC, Lowenstein J, Bigelow B, Meltzer M. Heavy chain disease: A new disorder; report of the first case. Am J Med 1964;37:332-50.

${ }^{18}$ Osserman EF, Takatsuki K. Clinical and immunochemical studies of four cases of heavy (H gamma 2) chain disease. Am J Med 1964;37:351-73.

19 Bernier GM, Graham RC Jr. Asynchrony in myeloma cells. Parallel changes by light and electron microscopy (Abstract) Blood 1974;44:936.

${ }^{20}$ Polli EE, Lanzavecchia G, Bosisio M. Inclusion bodies of human plasma cells in some myeloproliferative disorders. Proc 5th int congr Electron Microscopy 1962;2:55-7. New York: Academic Press.

${ }^{21}$ Smetana K, Hermanski F, Kobliskova H, Pospisil V. A further note on the ultrastructure of myeloma plasmacytes. Neoplasma $1971 ; 18: 3-13$.

${ }^{22}$ Lam CWK, Stevenson GT. Detection in normal plasma of immunoglobulin resembling the protein of gamma-chain disease. Nature 1973;246:419-21.

${ }^{23}$ Mennherz HG, Goody RS. Proteins of contractile systems. Ann Rev Biochem 1976;45:427-65.

${ }^{24}$ Osawa F. Actin. In Subunits in Biological Systems. Timasheff SN et al. (eds). New York: Marcel and Dekker. 1971.

${ }^{25}$ Russo MA, Daniel JL, Holmsen H. Formation of cytosolic filaments in human platelets induced by metabolic inhibitors. Abs. Phila. Workshop on Haemostasis and Thrombosis. 1976; Philadelphia, Oct.

${ }^{26}$ Liquori AM. Minimum energy conformations of biological polymers. CIBA Foundation Symposium: Principles of Biomolecular Organization 1966: (Ed. Woltenholme GEW and Haeve O'Connor. Boston: Little, Brown and Company) 40-68.

${ }^{27}$ Buxbaum IN, Alexander A. Heavy chain disease (HCD) in man: partial purification and translocation of the mRNA coding for the deleted protein. Clin Res 1977; 25:334A.

Requests for reprints to: Dr C. Bartoloni, c/o Istituto di Patologia Generale, Università Cattolica del S. Cuore, Via Pineta Sacchetti 644, I-00168 Roma, Italy. 